DE DE GRUYTER

OPEN
Journal of Intercultural Management

Vol. 7, No. 2, June 2015, pp. 113-123

DOI 10.1515/joim-2015-0013

Maria Jabłońska-Wołoszyn ${ }^{31}$

University of Social Sciences

\title{
Organizational Culture Based on Competences in Public Service - Example of the Competency Model in the Customs Service
}

\begin{abstract}
Using competencies to manage business organizations and to base a competency model on attributes of a preferable organizational culture is a common practice in business. Competency criteria allow improvement of workers' performance by informing them what behaviors further achieving the required organizational goals. Public organizations, faced with challenges of being a part of the European Union, have been learning how to use competencies to pursue new goals and create new organizational cultures of the offices.

The goal of this article is to present practices of the competencies evaluation usage in the Customs Service to shape behaviors accordingly to its preferable organizational culture. Key words: organizational culture, public organizations, competency management, employee evaluation.
\end{abstract}

\section{Organizational culture in relation to competencies}

Organizational culture is a term which is commonly used in management science due to its utilitarian description of organization. The search for determinants through which organizations create communities of workers based on specific values and standards, gave rise to organizational culture and its attributes. The term points out to the invisible part of an organization regulating behavior of its workers. According to G. Hofstede, that invisible part is a collective programming of the mind which distinguishes members of one organization from another one [Sikorski 2002].

\footnotetext{
${ }^{31}$ maria.woloszyn@wp.pl
} 
Based on the experiences of different organizations and their ways of management, it can be said that they have to identify and take into consideration attributes of culture in their practice of human resources management.

According to E. Schein [Koźmiński, Piotrowski 1999], the behavioral regulators which an organization should take into account in terms of personnel are as follow: - common language and a set of concepts - if participants don't have common language and don't use concepts which are known to the whole organization, effective communication among them is impossible.

- group boundaries, criteria of admission or rejection - setting conditions based on which it can be established who is and who is not a member of a particular organizational culture, allows to shape boundaries of an organization and increases integration of its workers.

- principles of power and criteria of status - position in a company hierarchy defines how authority can be gained, kept and used.

- addressing needs for safety and affiliation - knowledge of and adjustment to particular organizational culture requirements guarantee affiliation and safe functioning within that group.

- criteria of rewards and penalties; „religion” - obtaing knowledge of what is recognized as proper or improper in an organization creates a system of reinforcements unifying workers' convictions of what is a reward and punishment for them.

- ideologies functioning in organizations - giving sense to incomprehensible occurrences in an organization, creating a common vision of the world and an important anchorage in stressful situations.

We also talk about an effective organizational management when its organizational culture enhances implementation of strategic goals. In the subject literature, we can find statements indicating that especially, organizational culture of an organization creates its values and competitive position [Juchnowicz 2010]. Here is also emphasized the individual and unique approach toward shaping organizational behaviors determining attitudes and employees' values.

Following G. Hamelem i C.K. Prahaladem [Hamel, Prahalad 1989] who introduced the idea of "key competencies" relating to ways of thinking and a need to be the best on the market, more and more firms conduct organizational culture researches and define their attributes as the entry data to create their staffing policy. Personnel departments are required some assistance in management and creation of solutions supporting organizational goals implementation.

For an organization, its personnel policies understood as a set of rules concerning recruitment and development of employees, reinforcing also their commitment to firm's goals, should be connected with its organizational culture. According to the literature and business practice, in this case, especially useful solution is the approach based on a competency model. 
A competency model is defined as a behavioral description of a way to use employees' resources - predispositions, skills, knowledge and experience - to obtain particular organizational results [Fryczyńska, Jabłońska-Wołoszyn 2008]. The primary activity in the field of human resources management is to define, by using behavioral indicators, how employees are to operate based their organizational culture attributes and organizational effectiveness. The behavioral indicators form sets of competencies for particular jobs and constitute standards for employees' behaviors in that organization. Through the behavioral indicators, employees have both - additional measures describing a job well done, and knowledge of the range of their evaluation.

To make competencies more transparent and easier to use in an organization, they are grouped in categories to show the most important areas in which a competency model influences employees and their organization. From the perspective of organizational culture conditionalities, in a competency model the most important are:

- key competencies emerging from the core values and strategies of an organization, being a set of behaviors shared by all employees,

- managerial competencies which describe factors distinguishing managerial staff and their input in managing an organization.

It is particularly apparent in an organization based on knowledge, where the level of key and managerial competencies is the sum of the acquired education and the experience which was obtained while preforming more and more difficult duties required by the learning and teaching organization [Edwerstein Haas 2009].

\section{Character of Public organization culture in relations to competency model}

Public organizations are a specific type of organizations to which belong government, local and state administrations forming a consolidated organizational structure of a country. S. Wrzosek [Wrzosek 2008] points out that the systematic nature of personnel management of these organizations is used to the common good as a public mission involving mainly (but not only) execution of the policies which have the authority and material-and-technical resources.

Zimmerman [Zimmerman 2010] and Rostkowski [Rostkowski 2012] emphasize that recruiting personnel and organizing their work in public organizations take place with forms and principles governed by the law because the employees of public organizations have to serve public interest and fulfill public needs of their state. Due to its specific character, further in this article, the author will also use the term 'the office' to substitute the term' public organization'.

In a public organization we can distinguish a system of values which leads its life. Apart from mentioned above criteria of goals and missions of public organizations and their regulations of employment relationship, the system of values is determined by [Bińczycki 2005]: 
- specific behavior of employers who are representatives of a state or local government,

- specificity of consumer behavior of a client who is also a citizen and a constitutional rights holder,

- legalism of work and decision making including: the legalities, promptness of administrative tasks deliverance, and still insufficient innovativeness,

- high public expectations of the officials and their proper behavior at and after work, as well as their political neutrality and impartiality.

Mentioned above factors should be the base for building competency models in public organizations. However, according to the earlier conclusions, the specificity of public organizations needs to be taken into consideration in order to create for particular state services, "particularly tailored" competency models.

Enriching solutions of personnel management by competency models allows to focus attention on new ways of work for an official who is open to new challenges facing public organizations. So, creating a competency model for an organization based on the specificity of its organizational culture, one can use the approach based on "empty page". It is to identify employees' behaviors specific to their role in a particular public office and to describe these behaviors from scratch using behavioral indicators.

Defining competencies for a specific competency model is based on deep analyses of information characterizing that particular office while involving its most vital representatives. The most significant methods used to connect a competency model with an organizational culture are [Jabłońska-Wołoszyn 2012]:

- strategic workshop which is a meeting with the most important representatives of the office who are directly responsible for individual organizational units determined by the legislator. The goal of a strategic workshop is to identify competencies which currently condition the formal functioning of the office and its future challenges. Most often, the outcome of a strategic workshop is a concept of key and managerial competencies;

- expert panel which is a meeting with representatives of organizations directly connected with a post or a group of posts; direct manager, worker and inside client participate in it. The goal of expert panels is to define managerial and specialistic competences;

- examination of organizational and personnel records is based on analysis of different documents connected with key areas and processes in the office and defining requirements which are faced by workers in all categories of competencies;

- direct interviews with workers are directly connected with particular jobs/ functions. The goal of direct interviews is to analyze a job and define further specific competencies;

- interview of behavioral events analyzes critical events in behavioral aspects events which resulted in a success or failure at work; 
- work observation aims at describing work results and defining competencies which brought the results.

The outcome of this multi-faceted process of defining competencies is specific data containing definitions of competencies and their fulfilment dimensions - from minimal to maximal. The data indicate the level of responsibilities for a worker in the office. The solution presented above, which closely relates to business organizations, is innovative for public organizations. The innovativeness is based on a different way of preparing regulations in the office - from prescriptive to participatory.

\section{Key competencies in the Customs Service}

Crating a competency model in the Customs Service relates directly to the need of supporting human resources processes such as: internal and external recruitment, assessment, training and development, building development and career paths, in the Customs Service.

In accordance with the approach based on the "empty page" method, the process of defining the competency model for the Customs Service took into account the following activities [Internal material 2014]:

- research of the organizational culture of the Customs Service;

- analysis of the organizational documents: Customs Service Business Strategy for years 2010-2015+, 3I Customs Service from modernization to innovation, the Code of Ethics for Customs Officers, Anti-corruption Program of the Polish Customs Service for years 2010-2013+, Customs Service Act;

- conducting and elaborating strategic interviews with the Chief of the Customs Service and selected representatives of the management of the Customs Service. The interviews were conducted based on a questionnaire composed of short descriptive stories (success stories) and open questions;

- conducting expert panels with superiors and subordinates, in order to calibrate the content of the competencies and the level of their completion.

As the result of the described above activities, the competency model for the whole organization was built. Competencies were defined as "psycho-social abilities used in relations with other people in order to obtain expected effectiveness, also to initiate and sustain positive relationships" [Internal... 2014].

Accepted by the office, the competency definition refers to behavioral and language artefacts of an organizational culture which shape relations within and outside that organization. The competency model, in the Customs Service called interpersonal competencies, differentiate the following competencies:

- organization wide, common to all officers, reflecting the values appreciated in the Customs Service and linked to its strategy

- "family", assign to particular family of jobs/posts

- managerial, required with the jobs connected with work subordination 
The office treats the model as a document which is „alive”, and directed toward the future. Therefore, in 2013 the document was modified according to the European Commission recommendation on the common solutions implementation for national competency models.

The document, EU Customs Competency Framework identified basic values for EU customs services. They are:

- High ethical standards;

- Identification with public service;

- Client focus;

- Continuing education and professional development;

- Appropriate functioning in an organization;

- Harmonized approach toward the European Union;

- European security focus.

All customs officers should identify themselves with the values described above in order to improve customs services and obtain better organizational results. Forgoing recommendations reflect the key competencies for the Customs Service which are presented below.

\section{Table 1. Key competencies of the Customs Service}

\begin{tabular}{|l|l|}
\hline Competency & Definition \\
\hline $\begin{array}{l}\text { Knowledge and } \\
\text { readiness to learn }\end{array}$ & $\begin{array}{l}\text { It indicates readiness and capabilities to upgrade one's own competencies } \\
\text { understood as knowledge, abilities and attitudes which enable effective } \\
\text { professional functioning. On the highest level it means sharing knowledge } \\
\text { and co-creating databases understood as collections of experiences and } \\
\text { expert knowledge. }\end{array}$ \\
\hline Client orientation & $\begin{array}{l}\text { It means a pursuit to know, understand and satisfy needs of internal } \\
\text { and external clients in the realm of customs services activities. It is also } \\
\text { readiness to make non-standardized efforts to solve problems and needs of } \\
\text { clients. On the lower levels it manifests itself in proper relations with clients } \\
\text { and attention to pass proper information from and to clients. On the higher } \\
\text { levels client orientation is manifested by engaging resources to meet client } \\
\text { needs. }\end{array}$ \\
\hline $\begin{array}{l}\text { Orientation } \\
\text { towards achieving } \\
\text { organizational } \\
\text { objectives }\end{array}$ & $\begin{array}{l}\text { It means a persistent pursuit towards achieving organizational objectives } \\
\text { by taking action to produce the best results, carrying out one's duties } \\
\text { effectively and efficiently and showing initiative to constant improvement } \\
\text { of methods and work tools. }\end{array}$ \\
\hline Accountability & $\begin{array}{l}\text { It means thorough and professional performance of one's duties, also } \\
\text { making sure that decisions and activities were in accordance with law, } \\
\text { politics, procedures and serve to protect national and social interests. It is } \\
\text { also readiness to suffer consequences of one's choices and behaviors. }\end{array}$ \\
\hline
\end{tabular}




\begin{tabular}{|l|l|}
\hline $\begin{array}{l}\text { Compliance } \\
\text { with the rules of } \\
\text { professional ethics }\end{array}$ & $\begin{array}{l}\text { It means that an officer's behavior on and after duty complies with values } \\
\text { named in the Code of Ethics for Customs Officers, particularly: honesty, } \\
\text { impartiality, belief in the principles of law, selflessness. The competency } \\
\text { defines a notion of the relationship between an officer and the Customs } \\
\text { Service as an organization with its objectives. It manifests itself in } \\
\text { behaviors according to the rules of professional ethics, even in difficult and } \\
\text { risky situations. It also indicates taking actions to build a positive image of } \\
\text { the Service. }\end{array}$ \\
\hline $\begin{array}{l}\text { Readiness to } \\
\text { change }\end{array}$ & $\begin{array}{l}\text { It is an active attitude towards approaching changes, also an ability to adapt } \\
\text { to new situations and challenges, a capability to take adjusting actions and } \\
\text { implement them further. }\end{array}$ \\
\hline
\end{tabular}

Source: Internal material of the Customs Service Department, the Competency Model of the Customs Services, 2014

\section{Evaluation of key competencies of managers in the Customs Service}

One of the stages of implementation of the competency model in the Customs Service was the competency evaluation of the managerial staff. The subject of evaluation was the managerial competency profile which contained the following key competencies: orientation towards achieving organizational objectives and readiness to change. As it was mentioned before, key competencies allowed to codify attributes of the organizational culture in the managerial practice of the Customs Service. The use of key competencies of the managerial staff was to: stimulate development of individual competencies in work teams and motivate subordinates to new ways of thinking and behaving. Among the managers of the Customs Service the following behaviors within the framework of key competencies were expected:

Table 2. Behavioral indicators of expected level of key competencies of midmanagement of the Customs Service

\begin{tabular}{|l|l|}
\hline $\begin{array}{l}\text { Orientation towards achieving organizational } \\
\text { objectives } \\
\text { Expected level (4) - sets new goals }\end{array}$ & $\begin{array}{l}\text { Readiness to change } \\
\text { Expected level (3) - initiates }\end{array}$ \\
\hline $\begin{array}{l}\text { sets difficult, but possible to implement goals } \\
\text { monitors undertaken activities and makes } \\
\text { needed corrections at the correct stage of an } \\
\text { activity }\end{array}$ & $\begin{array}{l}\text { initiates new solutions } \\
\text { has abilities to persuade changes } \\
\text { is able to evaluate risks during changes } \\
\text { communicates to others a need for changes } \\
\text { engages means and time to achieve goals } \\
\text { pays attention to quality of suggested solutions }\end{array}$ \\
\hline
\end{tabular}

Source: Internal material of the Customs Service Department, the Competency Model of the Customs Services, 2014 
The purpose of the key competencies evaluation was to diagnose gaps which affect work efficiency and the managerial staff adaptation to changes taking place in the Customs Service. To diagnose Directors of the Customs Chambers and Heads of the Customs Offices the method of Assessment Center was used. This method has precise work standards. A multidimensional process of the management competencies evaluation done by independent and objective assessors was applied here [Fryczyńska 2014]. To evaluate the competencies, the following tasks were used:

- Group task - Group discussion;

- Individual task - Tasks Basket with Presentation;

- Individual task - Meeting with Subordinates;

- Competencies Base Interview.

Forty managers participated in the evaluation. They got the following results:

\section{Graph 1. Competence evaluation: Orientation towards achieving organizational objectives}

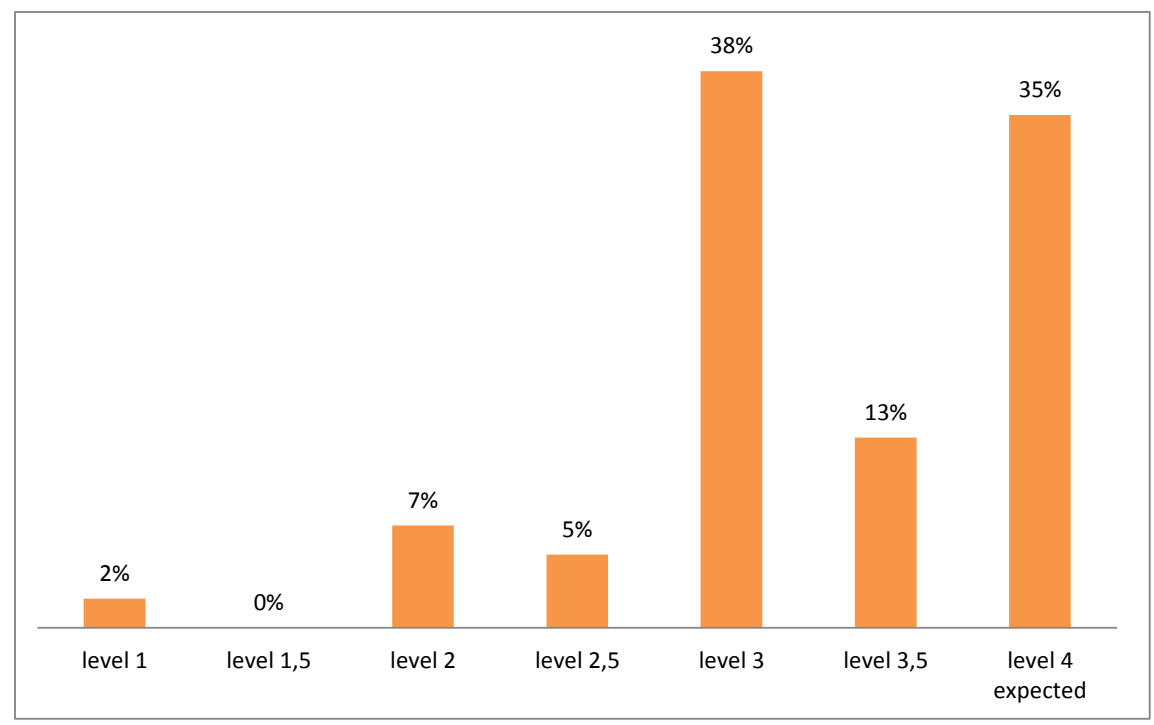

Source: Internal material of the Customs Service Department, the Competency Model of the Customs Services, 2014

As it shows on the distribution of results, more than $1 / 3$ of participants $(35 \%)$ presented the expected level of competencies, level 4. Half of the people (51\%) obtained level 3 or 3.5, only 15\% of participants got results below level 3 .

To the strengths of the group the following were accounted:

- proper identification of goals which they were facing. Referring, by part of the group, to the strategic objectives of the organization: efficiency and stability of 
the organization, obtaining good financial results, optimization of activities and costs, good quality of customer service and customer satisfaction as the base for functioning of the organization.

- taking responsibilities to fulfill the objectives and define methods of achieving them, generating specific and of high quality solutions.

Participants who during DC did not get the expected level of competencies, mostly showed deficit in: communicating opportunities and risks, searching for optimal and of good quality solutions, implementing the tools to monitor planned activities.

\section{Graph 2. Competence evaluation: Readiness to change}

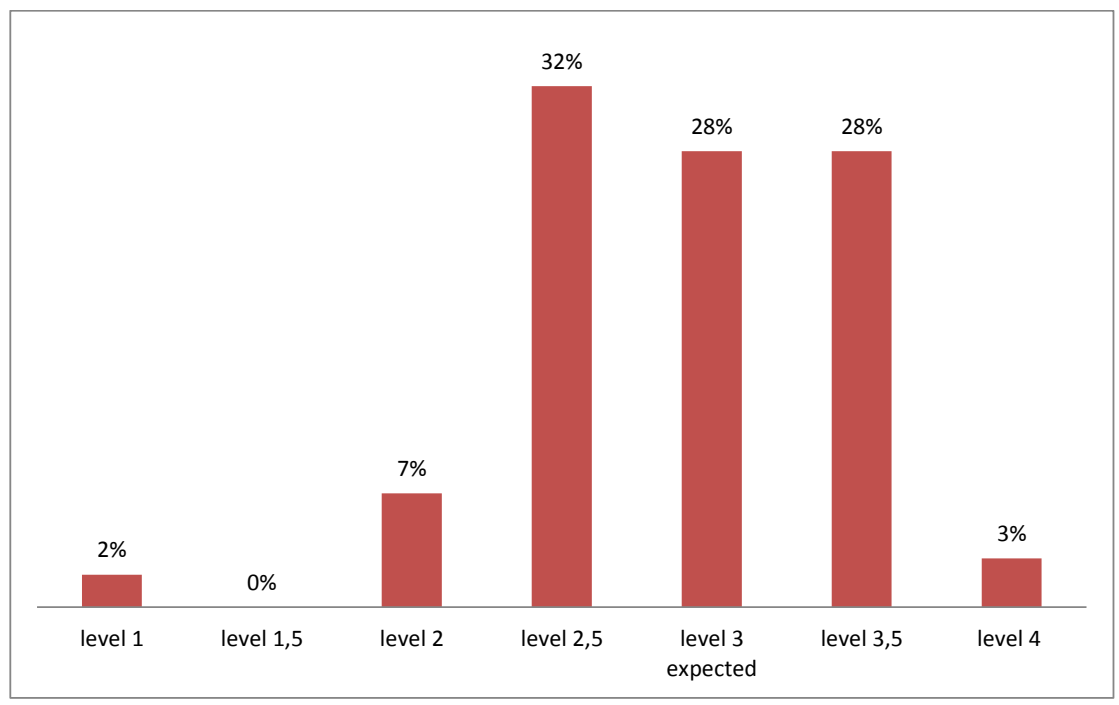

Source: Internal material of the Customs Service Department, the Competency Model of the Customs Services, 2014

The distribution of results of this competence indicates that expected level 3 was obtained by $1 / 3$ of participants $(28 \%)$; also $1 / 3$ of participants $(31 \%)$ presented readiness to change on the level exceeding the expected level. The remain people (41\%) got the results below the expected level 3.

Participants who obtained results above the expected level, presented solid abilities in a change management supported by persuasive communication. Those people undertook effective activities to engage others in the process and created an atmosphere allowing new ideas to breed.

They also generated many solutions themselves and implemented the outcome of changes to improve the results of their group. Furthermore, they emphasized 
reason-oriented communication and purposeful changes showing new possibilities for the organization and workers. Some of them pointed out negative consequences of not implementing the changes (job losses, declining condition of a firm, client losses).

It can be noticed, that the majority of participants presented the suggestions as a plan which indicated specific priorities, involved people and a time frame.

Participants, who showed deficits in the realm of this competency, had difficulties with fast adjustment to changes, new tasks, and responsibilities. They didn't present positive attitudes toward new situations. They went from one task to another not communicating their believes, positive opinions and not generating positive views of a change.

Particularly important in the process of the competencies evaluation was to communicate the results to the evaluated managers. The office made sure that each of the participants received a personal feedback about the level of his or her competencies.

To eliminate competency gaps, together with an outside consultant, each evaluated manager worked out his/her individual plan to further develop the competencies. Analyzing development goals of the Customs Service managerial staff, it can be observed that majority of managers planned aside workshops, also self-development. It indicates that the staff took seriously the responsibilities of the audit results.

\section{Conclusion}

The purpose of this article was to show practices of using a competency model in the Customs Services to create a new organizational culture that reflected strategic challenges of this Service. The way the competency model was prepared and used to evaluate the managerial staff relates to the best competency management in business.

Engaging managers to build and implement tools based on competencies is a key factor in using competency models to support organizational cultures in business settings.

In the Customs Service this practice was exercised by the managerial staff implementing the knowledge about the competencies through the tools which verified the efficiency of competencies usage.

The application of both, business methods to build the competency model and Assessment Center to estimate competency gaps, validated readiness of the Customs Service to connect its human resources management with the organizational strategy and the changes in its organizational culture. 


\section{References}

Bińczycki B. (2005), Doskonalenie procesu zarzqdzania zasobami ludzkimi w administracji publicznej [in:] L. Kozioł (ed.) Zarzqdzanie sek.torem publicznym i prywatnym w społeczeństwie informacyjnym, Małopolska Wyższa Szkoła Ekonomiczna w Tarnowie, Tarnów, p. 20.

Ewdersheim Haas E. (2009) Przestanie Druckera, MT Biznes, Warszawa 2009, p. 191.

Fryczyńska M. (2014), Ocena kompetencji z zastosowaniem ośrodków oceny i ośrodków rozwoju (AC/ DC) [in:] M. Juchnowicz (red.), Zarzadzanie kapitatem ludzkim. Procesy, narzedzia, aplikacje, Warszawa: Polskie Wydawnictwo Ekonomiczne, pp. 377-386.

Fryczyńska M., Jabłońska-Wołoszyn M. (2008), Praktyczny prz̨ewodnik rozwoju zawodowego pracowników, PLACET, Warszawa.

Hamel G., Prahalad C.K. (1989), Strategic intent., "Harvard Busines Review”, May-June 1989, no 3, p. 48.

Jabłońska-Wołoszyn M. (2012), Aspekty wdrożeniowe wykorzystania kompetencji w ZZL, „Przedsiębiorczość i Zarządzanie”, tom XIII, zeszyt 15.

Juchnowicz M. (2010), Zarzadzanie præez zaangażowanie. Koncepcja. Kontrowersje. Aplikacje, Polskie Wydawnictwo Ekonomiczne, Warszawa.

Koźmiński A., Piotrowski W. (red.), Zarzqdzanie teoria i praktyka, PWN, Warszawa 1999, p. 463.

Materiał wewnętrzny Departamentu Służby Celnej, Model kompetencji, maszynopis powielony, 2014.

Materiał wewnętrzny Departamentu Służby Celnej, Wyniki Audytu Służby Celnej, maszynopis powielony, 2014.

Rostkowski R. (2012), Strategicそne zarzadzanie zasobami lud₹kimi w administracji publiçnej, Wolters Kluwer Polska,, Warszawa, p. 23.

Sikorski Cz. (2002), Kultura organizacyjna, C. H.Beck, Warszawa, s. 2.

Wrzosek S. (2008), System: administracja publiçna, Systemowe determinanty nauki administracji, Katolicki Uniwersytet Lubelski, p. 18.

Zimmermann J. (2010), Prawo administracyjne, Wolters Kluwer Polska, Warszawa, p. 28. 